УДК 656.072.21

\title{
УДОСКОНАЛЕННЯ ОБСЛУГОВУВАННЯ ПАСАЖИРІВ НА ОСНОВІ РАЦІОНАЛІЗАЦЇ̈ СХЕМ ФОРМУВАННЯ ПАСАЖИРСЬКИХ ПОЇЗДІВ
}

Слухач ІППК Х.В. Байрачна, канд. техн. наук О.А. Малахова

\section{СОВЕРШЕНСТВОВАНИЕ ОБСЛУЖИВАНИЯ ПАССАЖИРОВ НА РАЦИОНАЛИЗАЦИИ СХЕМ ФОРМИРОВАНИЯ ПАССАЖИРСКИХ ПОЕЗДОВ}

ОСНОВЕ

Слушатель ИППК К.В. Байрачная, канд. техн. наук Е.А. Малахова

\section{IMPROVING SERVICE OF PASSENGER TO BASED RATIONALIZATION SCHEMES FOR THE FORMATION OF A PASSENGER TRAIN}

Listener IPPK C Bajrachnaya, cand. of techn. sciences O. Malakhova

На основі прогнозних значень пасажиропотоків розроблена математична модель встановлення функиіі попиту пасажирів на перевезення в дальньому сполученні. При изьому враховано, щзо кожна категорія місць у вагоні поӥзда дальнього сполучення має задовольняти ту чи іншу потребу пасажира в перевезенні.

Ключові слова: пасажиропотік, попит, прогнозування, схеми формування.

На основе прогнозных значений пассажиропотоков разработана математическая модель определения функции спроса пассажиров на перевозки в дальнем сообщении. При этом учтено, что каждая категория мест в вагоне поезда дальнего следования долюна удовлетворять той или иной потребности пассажсиа в перевозке.

Ключевые слова: пассажиропоток, спрос, прогнозирование, схемы формирования.

Prediction of passenger traffic (both distant connections and short distances) in modern terms is for the railroad one aspect of governmental activity. Short-term forecasting makes it possible to respond to the changing situation on the market of railway transportation and railway to build a strategy based on the expected volume of passenger traffic.

Based on the predictive values of passengers establishing a mathematical model of the demand for passenger transport in the far traffic. In this case, taking into account that each category for a train distant connections must meet a particular need of the passenger traffic.

Keywords: passenger demand, forecasting, circuit formation.

Рівень економічного і соціального розвитку держави багато в чому визначається його транспортно. забезпеченістю.

Залізничний транспорт - одна 3 найважливіших базових галузей економіки. Він відіграє ключову роль у забезпеченні транспортних потреб населення та економіки країни. При розгалуженості залізничних ліній найважливішими чинниками економічного i соціального розвитку країни $\epsilon$ проведення економічних перетворень, зміцнення соціально- економічної єдності країни, нормального функціонування складного господарського комплексу. Залізничний транспорт - один 3 основних інструментів раціонального розвитку i розміщення виробничих сил, оптимізації господарських зв'язків, розроблення та впровадження нових альтернативних джерел паливних ресурсів.

Пасажирські перевезення на залізничному транспорті - найважливіша складова перевізного процесу, однією 3 
особливостей яких $€$ яскраво виражений соціальний характер, оскільки перевезення різних категорій населення зачіпає інтереси мільйонів пасажирів.

Для збільшення прибутковості пасажирського комплексу необхідно визначити шляхи, що дадуть змогу підвищити ефективність функціонування системи освоєння пасажиропотоків [1]:

- скоротити витрати на перевезення пасажирів при одночасному підвищенні якості перевезень та забезпеченні безпеки, комфортабельності, терміновості;

- підвищити конкурентоспроможність пасажирського залізничного транспорту;

- винайти можливість надання якісно нових додаткових послуг пасажирам далекого прямування.

У сучасних умовах експлуатації залізничного транспорту найважливішого значення набувають економіко - математичні методи управління і організації пасажирських перевезень, спрямовані на задоволення вимог пасажирів при одночасному скороченні витрат залізничного транспорту.

Питаннями підвищення ефективності пасажирських перевезень на залізничному транспорті займалися багато видатних вчених, такі як: М.І. Данько, Т.В. Бутько, В.Г. Шубко, Н.В. Правдін, Ю.О. Пазойський, Ю.В. Слизарьєв, Е.А. Юркова, В.В. Тітов, С.Б. Єлізаров, О.А. Нікітін, К.А. Сєнцова, В.В. Мішанін, А.А. Попов, П.О. Яновський i багато інших наукових діячів. Усі вони у своїх роботах шукали шляхи вирішення існуючих на залізниці проблем удосконалення пасажирських перевезень, використовуючи різні форми: статистичний аналіз, анкетування, прогнозування й інші наукові дослідження.

Ефективність пасажирських перевезень залежить від кількості перевезених пасажирів та способів заохочення нових клієнтів до перевезень саме залізничним транспортом.

Прогнозовані обсяги пасажиропотоку впливатимуть на розміри руху поїздів різних напрямків.

При нормуванні розмірів руху пасажирських поїздів, їх маси i швидкості необхідно забезпечити:

- повне і своєчасне задоволення потреб населення у перевезеннях 3 різним рівнем наданого сервісу;

$$
\text { - мінімально можливу }
$$

кількість пересадок пасажирів;

- високі швидкості прямування пасажирських поїздів для зменшення часу перебування пасажирів на шляху прямування;

- ефективне використання рухомого складу i ресурсів пропускної спроможності залізничних напрямків;

- роботу напрямків ділянок залізниць 3 урахуванням забезпечення пропуску вантажних i пасажирських поїздів приміського та місцевого сполучень.

Правильне визначення числа призначень далеких i місцевих пасажирських поїздів на мережі залізниць має сприяти, 3 одного боку, повному задоволенню потреб суспільства в перевезеннях, 3 іншого боку - більш ефективному використанню залізничної інфраструктури, в тому числі рухомого складу.

Розміри руху встановлюються на підставі таких чинників:

- потужності i характеру розподілу пасажиропотоків на залізничних напрямках;

- вагових норм пасажирських поїздів;

- категорій пасажирських поїздів і дальності їх прямування;

- схеми составів пасажирських поїздів i місткості пасажирських вагонів;

- техніко-економічних характеристик залізничних напрямів.

Основою при визначенні розмірів руху пасажирських поїздів $\epsilon$ перспективні пасажиропотоки. Для визначення числа i призначень пасажирських поїздів необхідно знати густоту пасажиропотоків на кожній дільниці мережі залізниць. Розміри руху визначаються за найбільшою величиною розрахункового пасажиропотоку в парному або непарному напрямках.

Задача прогнозування обсягів пасажирських перевезень $€$ основою для вирішення багатьох задач оптимізації системи пасажирських залізничних перевезень за критеріями, безпосередньо пов'язаними 3 показником рентабельності (доходи, затрати, прибуток), оскільки оптимальність планів, отриманих при вирішенні цих завдань, залежить насамперед від точності прогнозів.

Останнім часом при прогнозуванні усе більше уваги приділяється нетрадиційним методам. Це пов'язано з появою нових способів обробки інформації. Серед них треба відзначити нейронні мережі. Відмітна риса 
методу прогнозування на основі нейронних мереж полягає у можливості використання в умовах нестабільних економічних ситуацій.

Переваги нейромережевих технологій такі:

- можливість вирішення практично

будь-якого завдання;

- завдання можуть бути недостатньо формалізовані, мати зашумлені й неправильні вхідні дані;

- відсутність усяких вимог до форми розподілу даних;

- можливість комбінування мереж;

- поєднання здатності комп'ютера до обробки чисел i здатності мозку до узагальнення й розпізнавання.

Розроблювана система дозволить вирішити завдання керування пасажирськими залізничними перевезеннями, грунтуючись на прогнозуванні обсягів перевезень за допомогою апарата нейронних мереж. Прогнозування - це ключовий момент при прийнятті рішень у керуванні залізничними перевезеннями.

Система підтримки прийняття рішень керування перевезеннями зможе не тільки спрогнозувати очікуваний пасажиро потік, але й визначити передбачувану рентабельність рейсів, очікуваний економічний ефект від зменшення або збільшення їхньої кількості, а також визначити найбільш оптимальні варіанти керування пасажирськими залізничними перевезеннями.

Одним із завдань, що вирішуються при побудові моделі попиту пасажирів, є вивчення формалізованої (описаної за допомогою засобів математики) теорії поведінки пасажира. Математична модель має пояснити, яким чином визначається вибір місць кожним пасажиром.

Очевидно, доступні набори місць визначаються, по-перше, заданими цінами на квитки відповідних категорій, а по-друге, певним доходом, який має у своєму розпорядженні споживач транспортних послуг, тобто проблема індивідуального вибору пасажира полягає у вирішенні питання про те, якої категорії квиток він може придбати при заданих цінах на перевезення і відповідному доході.

Кожна категорія місць у вагоні поїзда дальнього сполучення має задовольняти ту або іншу потребу пасажира в перевезенні. Здатність задовольняти різні споживчі потреби називають корисністю блага [2]. Вибір пасажиром одного набору місць із множини доступних йому залежить від його пріоритетів, фізичних мож- ливостей, звичок тощо. Отже, при розгляді двох різних наборів місць у вагонах різних категорій $a=\left(x_{1}, x_{2}, \ldots, x_{n}\right) \quad$ i $\quad b=\left(y_{1}, y_{2}, \ldots, y_{n}\right)$ пасажиру потрібно вирішувати такі питання:

- набір місць $x$ більш переважний (корисніший), ніж набір місць $y$;

- набір місць $y$ більш переважний, ніж набір місць $x$;

- набори місць $x$ i $y$ рівні (однаково корисні, рівноцінні, рівнозначні).

Дане поняття відношення переваги дозволяє сформулювати такий принцип вибору споживача: пасажир обирає найбільш переважний набір місць у вагонах різних категорій із множини доступних йому. Але такий підхід не завжди є зручним, тому скористаємося логарифмічною функцією корисності для переваги одного набору місць над іншим.

Функція корисності може бути визначена як для всіх наборів місць у вагонах різних категорій $a=\left(x_{1}, x_{2}, \ldots, x_{n}\right)$, так і для кожного місця окремо, тобто для кожного місця $j$ визначається своя функція корисності $u_{j}=\left(x_{j}\right)$.

$$
u(x)=\sum_{j=1}^{n} a_{j} \ln x_{j}
$$

причому $a_{j}>0, x_{j}>0, j=\overline{1, n}$, де $a_{j}$ - коефіцієнт функції опитування.

Функція корисності $u(x)$, по суті, зображує систему пріоритетів пасажира. Основна ii властивість полягає в тому, що пасажир віддає перевагу $x$, a не $y$, якщо $u(x)>u(y)$, тобто функція упорядковує набори місць у вагонах різних типів за рівнем переваги їх один над одним. Отже, пасажир при виборі набору місць прагне до максимізації своєї функції корисності.

Оскільки перевага пасажира при виборі категорії вагона виражається цільовою функцією $u(x)$, то модель вибору категорії вагона пасажиром має вигляд такого завдання математичного програмування [3]:

$$
u(x)=\left(x_{1}, x_{2}, \ldots, x_{n}\right) \rightarrow \max u
$$

при таких обмеженнях 


$$
\left\{\begin{array}{l}
\sum_{j=1}^{n} p_{j} x_{j} \leq M, \text { за місткістю состава } \\
x_{j} \geq 0, j=\overline{1, n}, \text { за наявністю пасажирів }
\end{array}\right.
$$

Отримана функція попиту може бути використана при вирішенні завдань оптимізації плану формування пасажирських поїздів дальнього прямування 3 врахуванням запиту пасажирів на різні категорії місць, а також для оцінки задоволення попиту на залізничні перевезення.

На рисунку наведені гістограми розподілу коефіцієнта щодобового використання місць купейних, плацкартних та люксів пасажирських поїздів, а в таблиці статистичні параметри розподілу щодобової нерівномірності пасажиропотоків. Із наведених даних бачимо, що найбільш стійкий попит мають місця у плацкартних вагонах, для яких середній коефіцієнт використання місткості складає 0,78 та 0,87 для непарного та парного напрямків відповідно. Однак і для цих вагонів ступінь використання місць в окремі періоди складає менш ніж 60 \%. Для купейних вагонів та особливо люксів середній коефіцієнт використання місткості має менше значення та перебуває в межах 55-75 \%. Відповідно більше значення для цих вагонів має коефіцієнт варіації випадкової величини. Причиною такого положення $\epsilon$ те, що состав у пасажирського поїзда коригується в окремі дні і пасажиропотік має дуже складну природу для прогнозування.
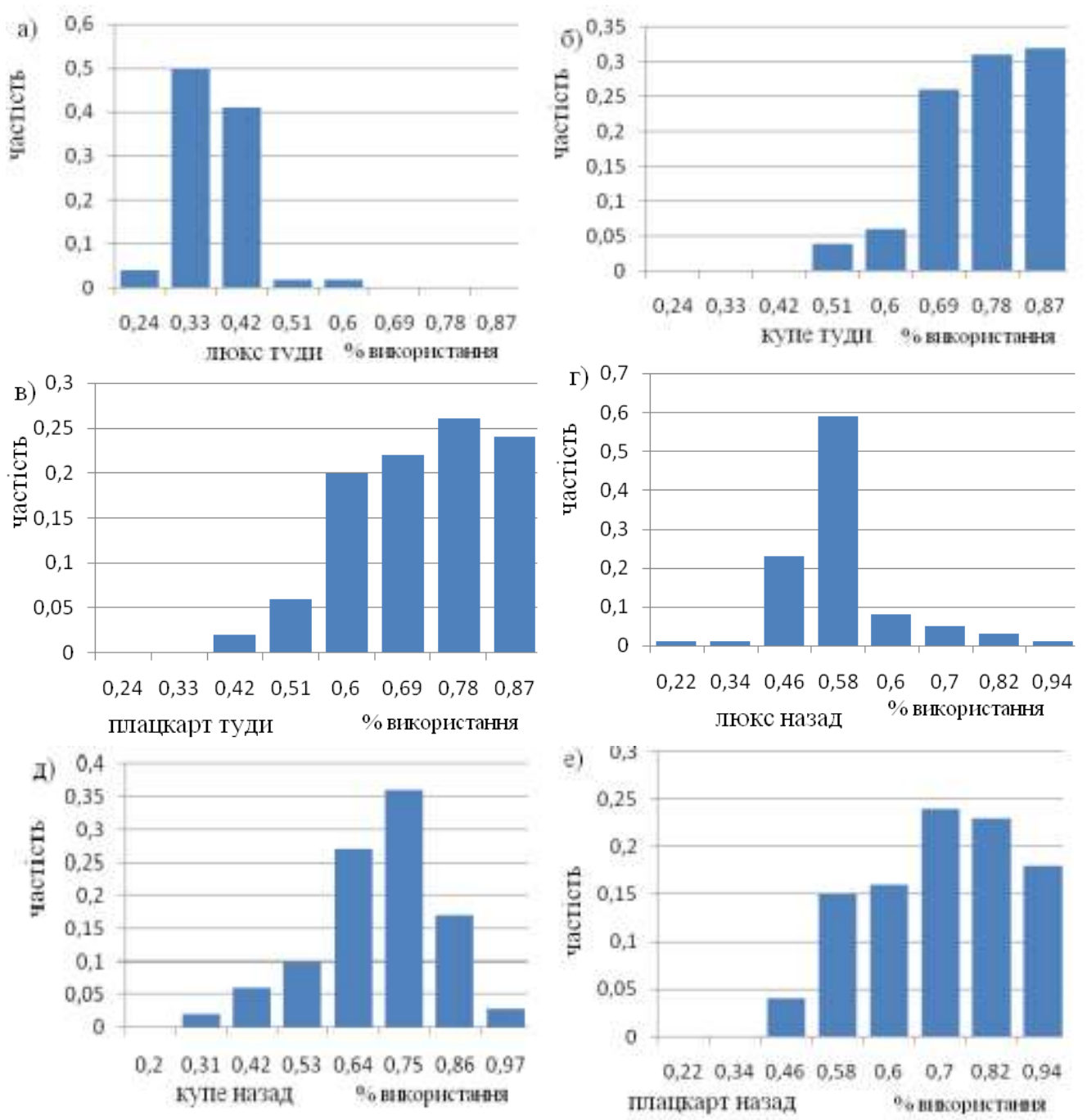

Рис. Гістограми розподілу коефіцієнта щодобової нерівномірності використання місць у вагонах: а,б,в - відповідно люксах, купейних та плацкартних парного напрямку; г,д,е - відповідно люксах, купейних та плацкартних непарного напрямку 
Статистичні параметри розподілу щодобової нерівномірності пасажиропотоків у вагонах пасажирського поїзда

\begin{tabular}{|l|c|c|c|c|c|c|}
\hline \multirow{2}{*}{ Найменування параметрів } & \multicolumn{5}{|c|}{ Значення параметрів для вагонів: } \\
\cline { 2 - 7 } & \multicolumn{5}{|c|}{ парного напрямку } & \multicolumn{3}{c|}{ непарного напрямку } \\
\cline { 2 - 7 } & люкс & купе & плацкарт & люкс & купе & плацкарт \\
\hline $\begin{array}{l}\text { Середнє значення } \\
\text { експериментального ряду }\end{array}$ & 0,37 & 0,76 & 0,72 & 0,57 & 0,7 & 0,73 \\
\hline Дисперсія & 1,12 & 0,37 & 0,31 & 0,72 & 0,36 & 0,27 \\
\hline $\begin{array}{l}\text { Середнє квадратичне } \\
\text { відхилення }\end{array}$ & 1,06 & 0,61 & 0,56 & 0,85 & 0,6 & 0,52 \\
\hline Коефіцієнт варіації & 2,86 & 0,8 & 0,78 & 1,49 & 0,86 & 0,71 \\
\hline
\end{tabular}

Для покращення якості використання пасажирських вагонів та зменшення витрат на пасажирські перевезення формують состави змінної довжини та композиції залежно від попиту.

Висновок. Перевезення пасажирів залізничним транспортом постійно конкурують на ринку транспортних послуг із автомобільним транспортом. Для збільшення обсягів пасажирських перевезень необхідно застосовувати всі заходи організаційного та реконструктивного характеру, серед яких збільшення швидкостей перевезень, оновлення рухомого складу, гнучка тарифна політика, покращення сервісу на вокзалах та в поїздах, розвиток інформаційних технологій.

\section{Список використаних джерел}

1. Марчук, Б.Е. Стратегия и приоритетные направления развития системы управления пассажирскими железнодорожными перевозками [Текст] / Б.Е. Марчук, Н.Н.Красильникова, Е.А. Макарова // Вестник ВНИИЖТ. - 2002. - № 5.

2. Пазойский, Ю.О. Математическая модель оптимизации пассажирских перевозок в дальнем сообщении [Текст] / Ю.О. Пазойский, Д.В. Глазков // Вестник ВНИИЖТ. - 2004. - № 2.

3. Корнев, С.А. Разработка системы поддержки принятия решений управления пассажирскими авиаперевозками ДонбассАэро: автореферат магистерской работы [Электронный ресурс]. - Режим доступа: http://www.masters.donntu.edu.ua/2006/kita/kornev/diss/index.htm.

Рецензент д-р техн. наук, професор О.М. Огар

Байрачна Христина Василівна, слухач ІППК Української державної академії залізничного транспорту. Тел.: 0956064031.

Малахова Олена Анатоліївна канд. техн. наук, доцент кафедри управління процесами перевезень Української державної академії залізничного транспорту. Тел.: 0663418481. E-mail: alena_mal@mail.ru/

Bajrachnaya Christine V., listener IPPK Ukrainian State Academy of Railway Transport. Tel.: 0956064031.

Malakhova Olena A. cand. of techn. sciences, associate professor of transportation management processes Ukrainian State Academy of Railway Transport. Tel.: 0663418481. E-mail: alena_mal@mail.ru. 